\title{
Comparative study of four Mystus species (Bagridae, Siluriformes) from Thailand: insights into their karyotypic diversity
}

\author{
Pun Yeesin', Phichaya Buasriyot ${ }^{2}$, Sukhonthip Ditcharoen²,
}

Patcharaporn Chaiyasan ${ }^{2}$, Chatmongkon Suwannapoom ${ }^{3}$, Sippakorn Juntaree ${ }^{4}$, Sitthisak Jantarat ${ }^{5}$, Sucheela Talumphai ${ }^{6}$, Marcelo de Bello Cioffi ${ }^{7}$, Thomas Liehr ${ }^{8}$, Alongklod Tanomtong ${ }^{2}$, Weerayuth Supiwong ${ }^{4}$

I Department of Technology and Industries, Faculty of Science and Technology, Prince of Songkla University, Pattani Campus, Muang, Pattani 94000, Thailand 2 Department of Biology, Faculty of Science, Khon Kaen University, Muang, Khon Kaen 40002, Thailand 3 Department of Fishery, School of Agriculture and Natural Resources, University of Phayao, Muang, Phayao 56000, Thailand 4 Applied Science Program, Faculty of Interdisciplinary Studies, Nong Khai Campus, Khon Kaen University, Muang, Nong Khai 43000, Thailand 5 Department of Science, Faculty of Science and Technology, Prince of Songkla University, Pattani Campus, Mueng, Pattani 94000, Thailand 6 Major Biology, Department of Science and Technology, Faculty of Liberal Arts and Science, Roi Et Rajabhat University, Roi Et 45120, Thailand 7 Departamento de Genética e Evolução, Universidade Federal de São Carlos (UFSCar), Rodovia Washington Luiz Km. 235, C.P. 676, São Carlos, SP 13565-905, Brazil 8 Jena University Hospital, Friedrich Schiller University, Institute of Human Genetics, Am Klinikum 1, D-07747, Jena, Germany

Corresponding author: Weerayuth Supiwong (supiwong@hotmail.com)

Academic editor: N. Bogutskaya | Received 11 November 2020 | Accepted 21 March 2021 | Published 26 April 2021

http://zoobank.org/25678369-D052-4116-ABCC-97D2A07850B6

Citation: Yeesin P, Buasriyot P, Ditcharoen S, Chaiyasan P, Suwannapoom C, Juntaree S, Jantarat S, Talumphai S, Cioffi MB, Liehr T, Tanomtong A, Supiwong W (2021) Comparative study of four Mystus species (Bagridae, Siluriformes) from Thailand: insights into their karyotypic diversity. CompCytogen 15(2): 119-136. https://doi. org/10.3897/compcytogen.v15.i2.60649

\begin{abstract}
Karyotypes of four catfishes of the genus Mystus Scopoli, 1777 (family Bagridae), M. atrifasciatus Fowler, 1937, M. mysticetus Roberts, 1992, M. singaringan (Bleeker, 1846) and M. wolffii (Bleeker, 1851), were analysed by conventional and Ag-NOR banding as well as fluorescence in situ hybridization (FISH) techniques. Microsatellite $\mathrm{d}(\mathrm{GC})_{15}, \mathrm{~d}(\mathrm{CAA})_{10}, \mathrm{~d}(\mathrm{CAT})_{10}$ and $\mathrm{d}(\mathrm{GAA})_{10}$ repeat probes were applied in FISH. The obtained data revealed that the four studied species have different chromosome complements. The diploid chromosome numbers (2n) and the fundamental numbers (NF) range between 52 and 102,
\end{abstract}

Copyright Pun Yeesin et al. This is an open access article distributed under the terms of the Creative Commons Attribution License (CC BY 4.0), which permits unrestricted use, distribution, and reproduction in any medium, provided the original author and source are credited. 
54 and 104, 56 and 98, or 58 and 108 in M. mysticetus, M. atrifasciatus, M. singaringan or M. wolffi, respectively. Karyotype formulae of $M$. mysticetus, $M$. atrifasciatus, $M$. singaringan and $M$. wolffi are $24 m+26 s m+4 a, 26 m+24 s m+2 a, 24 m+18 s m+14 a$ and $30 m+22 s m+6 a$, respectively. A single pair of NORs was identified adjacent to the telomeres of the short arm of chromosome pairs 3 (metacentric) in $M$. atrifasciatus, 20 (submetacentric) in M. mysticetus, 15 (submetacentric) in M. singaringan, and 5 (metacentric) in $M$. wolffi. The $\mathrm{d}(\mathrm{GC})_{15}, \mathrm{~d}(\mathrm{CAA})_{10}, \mathrm{~d}(\mathrm{CAT})_{10}$ and $\mathrm{d}(\mathrm{GAA})_{10}$ repeats were abundantly distributed in species-specific patterns. Overall, we present a comparison of cytogenetic and molecular cytogenetic patterns of four species from genus Mystus providing insights into their karyotype diversity in the genus.

\section{Keywords}

Chromosomes, fluorescence in situ hybridization (FISH), karyotype, Mystus

\section{Introduction}

Bagridae are the largest family of Thai catfishes, with six genera (Bagrichthys Bleeker, 1857, Batasio Blyth, 1860, Hemibagrus Bleeker, 1862, Mystus Scopoli, 1777, Pseudomystus Jayaram, 1968, and Sperata Holly, 1939) and 28 species in Thailand. They play an important role in the national economic value of the country, as they are kept in aquaria and contribute heavily to the aquaculture industry. Most species of the genus Mystus are booming in aquaculture, with some of them being kept in aquaria (Vidthayanon 2005). However, several species in this family are rather morphologically similar especially during the juvenile stage that may pose difficulties for their identification. Mystus is a poorly diagnosed group, and they are morphologically similar and diagnostic characteristics are usually subtle ( $\mathrm{Ng} 2003$; Ferdous 2013).

Cytogenetic studies on Thai bagrids are quite scarce; as yet only conventional cytogenetics have been applied to determine chromosome numbers and karyotype complements. Therefore, their chromosomal evolution is not clear, even though from family Bagridae up to 45 species have been karyotyped so far. The diploid chromosome number $(2 \mathrm{n})$ varies between $2 n=44$ [Coreobagrus brevicorpus Mori, 1936)] and $2 \mathrm{n}=80$ [Batasio fluviatilis (Day, 1888)]. The fundamental number (number of chromosome arms, NF) varies between 64 [for $M$. tengara (Hamilton, 1822) and M. vittatus (Bloch, 1794)] and 116 [for Horabagrus brachysoma (Günther, 1864) and H. nigricollaris Pethiyagoda et Kottelat, 1994] (Arai 2011).

Focusing on the genus Mystus, chromosomal diversity and chromosomal variations among populations can be found. The so far reported $2 \mathrm{n}$ for diploid chromosome numbers varies between 50 and 58 chromosomes and for NF from 64 to 110 (Table 1). Intra-specific variations of $2 \mathrm{n}$ were reported in M. mysticetus Roberts, 1992 $(2 \mathrm{n}=50,52)$ (Donsakul 2002; Supiwong et al. 2014a, b) and M. vittatus (Bloch, 1794) $(2 \mathrm{n}=50,54,58)($ Das and Srivastava 1973; Manna and Prasad 1974; Tripathi and Das 1980; Rishi 1981; Sharma and Tripathi 1986; Khuda-Bukhsh and Barat 1987; John et al. 1992; Choudhury et al. 1993; Ramasamy et al. 2010). The cytogenetic characterization of a species could be applied to other fields such as systematics, 
but also economic interests, as breeding practices of organisms by using chromosome set management (Na-Nakhon et al. 1980), strain improvement (Sofy et al. 2008) and brood stock selection (Mengampan et al. 2004).

Conventional cytogenetics may be sufficient to identify intra- and interspecific variations and is an inexpensive approach. However, it has restrictions, and accordingly the use of molecular cytogenetic analyses plays an increasing role for more precise characterization of the structure of genomes, including that of fishes. Especially, fluorescence in situ hybridization (FISH) for mapping of repetitive DNA sequences provided important contributions to the characterization of biodiversity and evolution in divergent fish groups (Cioffi and Bertollo 2012), especially as some microsatellite repeats are species-specific (Cioffi et al. 2015). To date, there are only three studies within Bagridae using such FISH techniques, all performed by our group (Supiwong et al. 2013a, 2014a, b).

In the present study, chromosomal structures and genetic markers for Thai populations of $M$. atrifasciatus Fowler, 1937, M. mysticetus, M. singaringan (Bleeker, 1846) and $M$. wolffi (Bleeker, 1851) (Fig. 1A-D) were for the first time analysed by cytogenetics and molecular cytogenetics.

\section{Material and methods}

Ten males and ten females of each species were collected from the Chi (Maha Sarakham Province), Songkhram (Bueng Kan Province), Chao Phraya (Sing Buri Province) and Pak Phanang Basins (Nakhon Sri Thammarat Province), Thailand from 2016-2018. The procedures followed ethical protocols as approved by the Institutional Animal Care and Use Committee of Khon Kaen University, based on the Ethics of Animal Experimentation of the National Research Council of Thailand ACUC-KKU-15/2559. Preparation of fish chromosomes from kidney cells was done as previously reported (Supiwong et al. 2012; Pinthong et al. 2015). The chromosomes were stained with Giemsa solution for 10 minutes. Ag-NOR banding was performed by applying two drops of $2 \%$ gelatin to the chromosomes, followed by four drops of $50 \%$ silver nitrate (Howell and Black 1980). Metaphases were evaluated according to the chromosome classification of Levan et al. (1964). Chromosomes were classified as metacentric (m), submetacentric (sm), subtelocentric (st) or acrocentric (a). Fundamental number, NF (number of chromosome arm) was obtained by assigning a value of two to metacentric and submetacentric chromosomes and one to subtelocentric and acrocentric chromosomes. The chromosome sizes were calculated applying the method of Tanomtong (2011).

Microsatellites $\mathrm{d}(\mathrm{GC})_{15}, \mathrm{~d}(\mathrm{CAA})_{10}, \mathrm{~d}(\mathrm{CAT})_{10}$ and $\mathrm{d}(\mathrm{GAA})_{10}$ repeat probes (Kubat et al. 2008) were directly labeled by Cy3 at 5' ends during synthesis (Sigma, St. Louis, MO, USA). FISH under high stringency conditions on mitotic chromosome spreads (Pinkel et al. 1986) was performed as previously reported (Supiwong et al. 2017b; Yano et al. 2017). The evaluation was done on an epifluorescence microscope Olympus BX50 (Olympus Corporation, Ishikawa, Japan). 


\section{Results}

Diploid number, fundamental number and karyotype of Mystus atrifasciatus, M. mysticetus, M. singaringan and M. wolffii

The four studied Mystus species have different diploid chromosome numbers (2n) and fundamental numbers (NF) as follows: the 2n (NF) were 52 (102), 54 (104), 56 (98) and 58 (108) in $M$. mysticetus, $M$. atrifasciatus, $M$. singaringan and $M$. wolffi, respectively. The karyotypes of $M$. atrifasciatus $(24 \mathrm{~m}+26 \mathrm{sm}+4 \mathrm{a})$, M. mysticetus $(26 \mathrm{~m}+24 \mathrm{sm}+2 \mathrm{a})$, $M$. singaringan $(24 \mathrm{~m}+18 \mathrm{sm}+14 \mathrm{a})$ and $M$. wolffi $(30 \mathrm{~m}+22 \mathrm{sm}+6 \mathrm{a})$ were species-specific (Fig. 1E-H; Table 1). Differentiated sex chromosomes between male and female specimens could not be identified in all analyzed species.

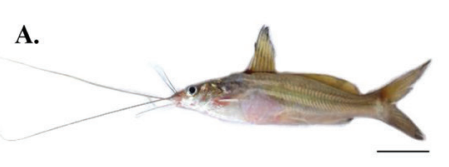

B.

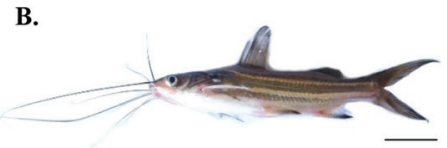

C.

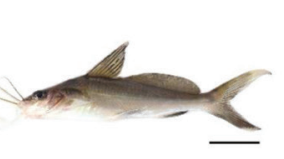

D.

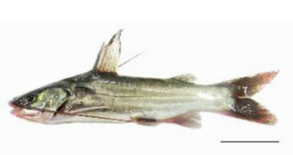

E.

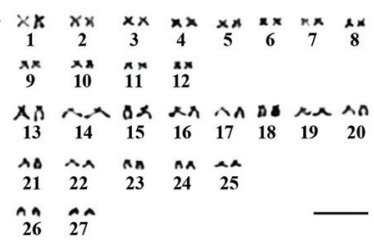

F.

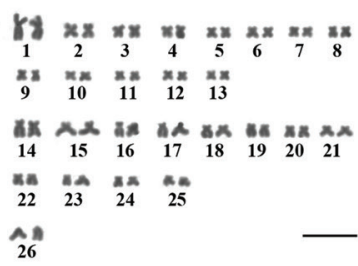

G.

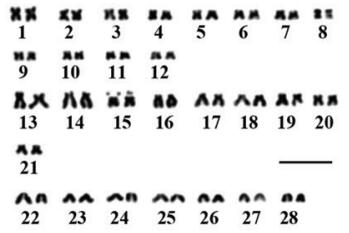

H.

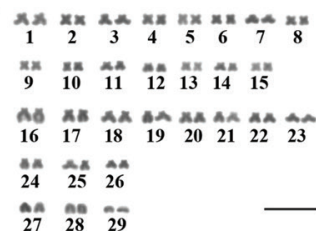

I.

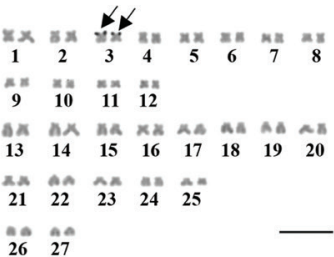

J.

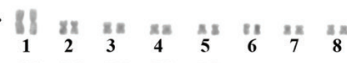

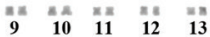

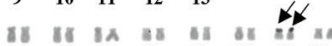
$\begin{array}{llllllll}14 & 15 & 16 & 17 & 18 & 19 & 20 & 21\end{array}$ $\begin{array}{lllll}42 & 23 & 24 & 25\end{array}$ 26

K.

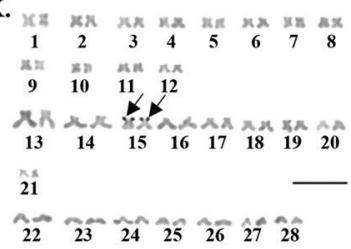

L.

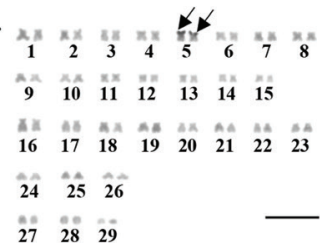

Figure I. Specimens and karyotypes from conventional staining and Ag-NOR banding techniques of Mystus atrifasciatus $(\mathbf{A}, \mathbf{E}, \mathbf{I}), M$. mysticetus $(\mathbf{B}, \mathbf{F}, \mathbf{J}), M$. singaringan $(\mathbf{C}, \mathbf{G}, \mathbf{K})$ and $M$. wolffi $(\mathbf{D}, \mathbf{H}, \mathbf{L})$; arrows indicate NOR carrying chromosomes. Scale bars: $2 \mathrm{~cm}(\mathbf{A}-\mathbf{D}) ; 5 \mu \mathrm{m}(\mathbf{E}-\mathbf{L})$. 
Table I. Comparative cytogenetics of Mystus genus ( $2 \mathrm{n}=$ diploid chromosome number, $\mathrm{m}=$ metacentric, $\mathrm{sm}=$ submetacentric, $\mathrm{st}=$ subtelocentric, $\mathrm{a}=$ acrocentric, $\mathrm{t}=$ telocentric, $\mathrm{NOR}=$ nucleolar organizer regions, $\mathrm{NF}=$ fundamental number, and $-=$ not available).

\begin{tabular}{|c|c|c|c|c|c|c|}
\hline Species & $2 n$ & NF & Karyotype & NOR & Locality & Reference \\
\hline Mystus albolineatus Roberts, 1994 & 56 & 108 & $28 m+6 s m+12 s t+10 a$ & - & Thailand (Ayutthaya) & Donsakul (2000) \\
\hline \multirow[t]{3}{*}{ M. atrifasciatus Fowler, 1937} & 54 & 92 & $30 m+8 s m+16 a$ & - & Thailand (Nakhon Phanom) & Magtoon and Donsakul (2009) \\
\hline & 54 & 96 & $24 m+18 s m+12 s t / a$ & & Thailand (Bueng Kan) & Supiwong et al. (2014 a, b) \\
\hline & 54 & 104 & $24 m+26 s m+4 a / t$ & 2 & Thailand (Maha Sarakham) & Present study \\
\hline \multirow[t]{2}{*}{ M. bleekeri (Day, 1877) } & 56 & 90 & $20 m+14 s m+10 s t+12 a$ & - & India (Jammu) & Sharma and Tripathi (1986) \\
\hline & 56 & 102 & $32 m+14 s m+10 a$ & - & India & Chanda (1989) \\
\hline \multirow[t]{2}{*}{ M. bocourti (Bleeker, 1864) } & 56 & 104 & $24 m+18 s m+6 s t+8 a$ & - & Thailand (Nong Khai) & Donsakul (2000) \\
\hline & 56 & 100 & $22 m+22 s m+12 s t / a$ & - & Thailand (Sing Buri) & Supiwong et al. (2013a, 2014a, b) \\
\hline \multirow[t]{3}{*}{ M. cavasius (Hamilton, 1822) } & 58 & 102 & $18 m+16 s m+10 s t+14 a$ & 2 & India (Jammu) & $\begin{array}{l}\text { Sharma and Tripathi (1986); } \\
\text { Rishi et al. (1994) }\end{array}$ \\
\hline & 58 & 108 & $18 m+22 s m+8 t$ & - & India (Orissa) & Tripathi and Das (1980) \\
\hline & 58 & 102 & $14 m+26 s m+4 s t+14 a$ & - & India (Bihar) & Khuda-Bukhsh et al. (1980) \\
\hline M. gulio (Hamilton, 1822) & 58 & 102 & $30 m+12 s m+2 s t+14 a$ & 2 & India (West Bengal) & Das and Khuda-Bukhsh (2007b) \\
\hline Female & 58 & 108 & $12 m+34 s m+4 s t+8 t$ & - & India (Orissa) & Choudhury et al. (1993) \\
\hline Male & 58 & 110 & $13 m+33 s m+4 s t+8 t$ & - & India (Orissa) & Choudhury et al. (1993) \\
\hline \multirow[t]{2}{*}{ M. multiradiatus Roberts, 1992} & 54 & 98 & $30 m+10 s m+4 s t+10 a$ & - & Thailand (Kanchana-buri) & Magtoon and Donsakul (2009) \\
\hline & 54 & 96 & $18 \mathrm{~m}+24 \mathrm{sm}+12 \mathrm{st} / \mathrm{a}$ & - & Thailand (Maha Sarakham) & Supiwong et al. (2014 a, b) \\
\hline \multirow[t]{3}{*}{ M. mysticetus Roberts, 1992} & 50 & 92 & $28 m+14 s m+8 a$ & - & Thailand (Ayutthaya) & Donsakul (2002) \\
\hline & 52 & 100 & $26 m+22 s m+4 s t / a$ & - & Thailand (Maha Sarakham) & Supiwong et al. (2014a, b) \\
\hline & 52 & 102 & $26 m+24 s m+2 a$ & 2 & Thailand (Bueng Kan) & Present study \\
\hline M. ngasep Darshan et al., 2011 & 56 & 90 & $12 m+22 s m+8 s t+14 t$ & - & India (Manipur) & Sing et al. (2013) \\
\hline \multirow[t]{2}{*}{ M. singaringan (Bleeker, 1846) } & 56 & 94 & $24 m+14 s m+10 s t+8 a$ & - & Thailand (Nakhonsawan) & Donsakul (2001) \\
\hline & 56 & 98 & $24 m+18 s m+14 a$ & 2 & Thailand (Sing Buri) & Present study \\
\hline M. tengara (Hamilton, 1822) & 54 & 64 & $10 m+44 a$ & - & India (Haryana) & Nayyar (1966) \\
\hline Female & 54 & 101 & $9 m+38 s m+7 a$ & - & India & Rishi (1973) \\
\hline Male & 54 & 102 & $10 m+38 s m+6 a$ & - & (Haryana) & Rishi (1973) \\
\hline Female & 54 & 97 & $25 m+18 s m+11 a$ & - & India & Rishi and Rishi (1981) \\
\hline Male & 54 & 98 & $26 m+18 s m+10 a$ & - & (Haryana) & Rishi and Rishi (1981) \\
\hline \multirow[t]{8}{*}{ M. vittatus (Bloch, 1794) } & 54 & 108 & $22 m+26 s m+6 s t$ & - & India (Orissa) & Tripathi and Das (1980) \\
\hline & 54 & 108 & $22 m+20 s m+12 s t$ & - & India (Jammu) & Sharma and Tripathi (1986) \\
\hline & 58 & 110 & $10 m+30 s m+12 s t+6 t$ & - & India (Orissa) & Choudhury et al. (1993) \\
\hline & 54 & 108 & $20 m+24 s m+10 s t$ & - & India & Rishi (1981) \\
\hline & 50 & 64 & $14 m+36 a$ & - & India & Das and Srivastava (1973) \\
\hline & 58 & 104 & $16 m+10 s m+20 s t+12 a$ & - & India (West Bengal) & Manna and Prasad (1974) \\
\hline & 54 & 106 & $28 m+22 s m+2 s t+2 a$ & 2 & India (Orissa) & $\begin{array}{l}\text { Khuda-Bukhsh and Barat (1987); } \\
\text { John et al. (1992) }\end{array}$ \\
\hline & 54 & 78 & $6 m+18 s m+30 a$ & - & India (Tamilnadu) & Ramasamy et al. (2010) \\
\hline \multirow[t]{2}{*}{ M. wolffi (Bleeker, 1851) } & 58 & 100 & $26 m+10 s m+6 s t+16 a$ & - & Thailand (Tak) & Donsakul (2000) \\
\hline & 58 & 108 & $30 m+22 s m+6 a$ & 2 & $\begin{array}{c}\text { Thailand (Nakhon Sri } \\
\text { Thammarat) }\end{array}$ & Present study \\
\hline
\end{tabular}

\section{Chromosome markers in Mystus atrifasciatus, M. mysticetus, M. singaringan and M. wolffii}

One single pair with NOR-bearing chromosomes was present in all four species analyzed. NOR positions were observed at regions adjacent to the telomere of the short arm of the chromosome pairs 3 (metacentric), 20 (submetacentric), 15 (submetacentric), and 5 (metacentric) in $M$. atrifasciatus, $M$. mysticetus, $M$. singaringan and M. wolffi, respectively (Figs 1I-L, 2). The typical diversity of chromosome shapes 


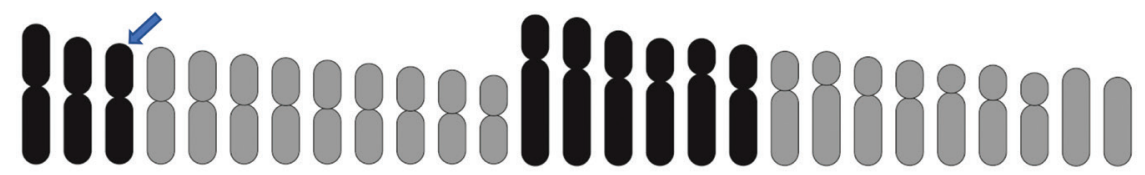

A.

$\begin{array}{lllllllllllllllllllllllllll}1 & 2 & 3 & 4 & 5 & 6 & 7 & 8 & 9 & 10 & 11 & 12 & 13 & 14 & 15 & 16 & 17 & 18 & 19 & 20 & 21 & 22 & 23 & 24 & 25 & 26 & 27\end{array}$

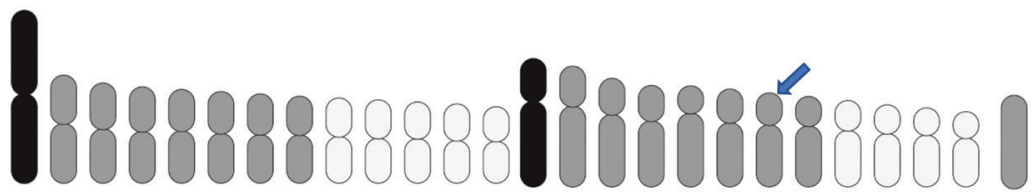

B.

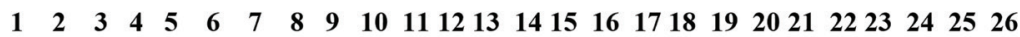

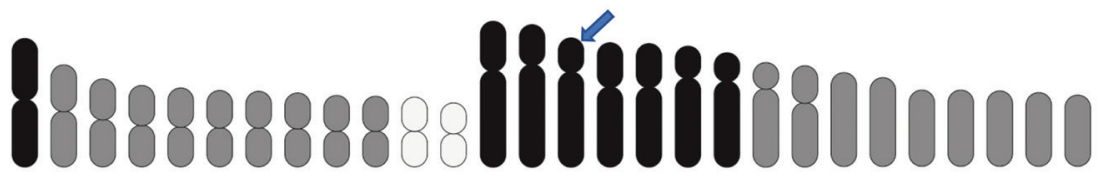

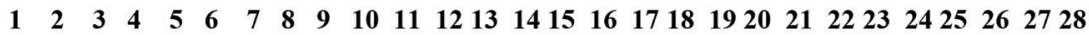

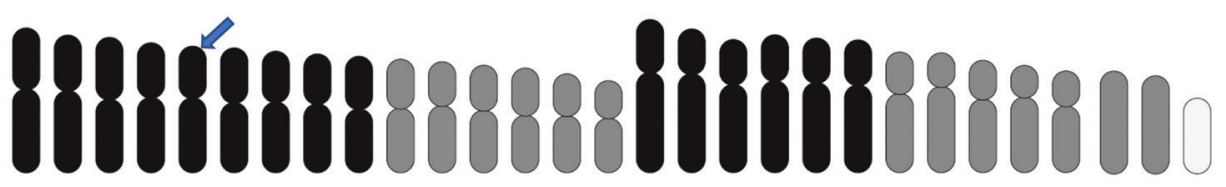

D.

$\begin{array}{lllllllllllllllllllllllllllll}1 & 2 & 3 & 4 & 5 & 6 & 7 & 8 & 9 & 10 & 11 & 12 & 13 & 14 & 15 & 16 & 17 & 18 & 19 & 20 & 21 & 22 & 23 & 24 & 25 & 26 & 27 & 28 & 29\end{array}$
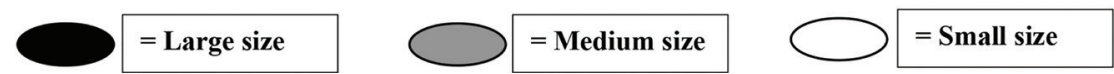

Figure 2. Idiograms representing shapes and sizes of chromosomes (haploid set) of A Mystus atrifasciatus B $M$. mysticetus $\mathbf{C}$ M. singaringan and $\mathbf{D} M$. wolffi; arrows indicate NOR carrying chromosomes.

Table 2. Cytogenetic and FISH studies on four Mystus fishes in Thailand ( $2 \mathrm{n}=$ diploid chromosome number, $\mathrm{NF}=$ fundamental number or number of chromosome arm, $\mathrm{m}=$ metacentric, $\mathrm{sm}=$ submetacentric, $\mathrm{a}=$ acrocentric, $\mathrm{NOR}=$ nucleolar organizer region, $\mathrm{I}=$ interstitial site, $\mathrm{T}=$ telomere, $\mathrm{W}=$ whole chromosome).

\begin{tabular}{|c|c|c|c|c|c|c|c|c|c|c|}
\hline \multirow[t]{2}{*}{ Mystus Species } & \multirow[t]{2}{*}{$2 n$} & \multirow[t]{2}{*}{ NF } & \multicolumn{3}{|c|}{ Chromosome type } & \multirow[t]{2}{*}{ Ag-NOR pair (type) } & \multicolumn{4}{|c|}{ Microsatellite patterns } \\
\hline & & & $\mathbf{m}$ & sm & $\mathbf{a}$ & & $(\mathrm{GC})_{15}$ & $(\mathrm{CAA})_{10}$ & $(\mathrm{CAT})_{10}$ & $(\mathrm{GAA})_{10}$ \\
\hline M. atrifasciatus Fowler, 1937 & 54 & 104 & 24 & 26 & 4 & $3(\mathrm{~m})$ & T\&I & T\&I & T\&I & I \\
\hline M. mysticetus Roberts, 1992 & 52 & 102 & 26 & 24 & 2 & $20(\mathrm{sm})$ & $\mathrm{T} \& \mathrm{I}$ & T\&I & $\mathrm{T} \& \mathrm{I}$ & $\mathrm{T} \& \mathrm{I}$ \\
\hline M. singaringan (Bleeker, 1846) & 56 & 98 & 24 & 18 & 14 & $15(\mathrm{sm})$ & $\mathrm{T} \& \mathrm{I}$ & $\mathrm{T} \& \mathrm{I}$ & $\mathrm{T}$ & $\mathrm{T} \& \mathrm{I}$ \\
\hline M. wolffii (Bleeker, 1851) & 58 & 108 & 30 & 22 & 6 & $5(\mathrm{~m})$ & W\&T & $\mathrm{T}$ & W\&T & $\mathrm{T} \& \mathrm{I}$ \\
\hline
\end{tabular}

and sizes among the four analyzed species is shown in Fig. 2 and Table 2. Karyotypic complements comprise most bi-armed and few mono-armed chromosomes revealed in $M$. atrifasciatus, $M$. mysticetus and $M$. wolffi whereas in $M$. singaringan, there are several pairs of both bi-armed and mono-armed chromosomes. Chromosome sizes are classified as large (L), medium (M) and small (S) in each species as follows: $18 \mathrm{~L}+36 \mathrm{M}$ in $M$. atrifasciatus, $4 \mathrm{~L}+30 \mathrm{M}+18 \mathrm{~S}$ in $M$. mysticetus, $16 \mathrm{~L}+36 \mathrm{M}+4 \mathrm{~S}$ in $M$. singaringan, and $30 \mathrm{~L}+26 \mathrm{M}+2 \mathrm{~S}$ in M. wolffi. 
Patterns of microsatellite repeats in the genomes of Mystus atrifasciatus, M. mysticetus, M. singaringan and M. wolffii

The mapping of $\mathrm{d}(\mathrm{GC})_{15}, \mathrm{~d}(\mathrm{CAA})_{10}, \mathrm{~d}(\mathrm{CAT})_{10}$ and $\mathrm{d}(\mathrm{GAA})_{10}$ microsatellites showed different hybridization signals among the species. The repeats of $\mathrm{d}(\mathrm{GC})_{15}$ and $\mathrm{d}(\mathrm{CAA})_{10}$ are abundantly distributed in the telomeric regions of several pairs and in interstitial sites of some chromosomes in $M$. atrifasciatus, M. mysticetus, M. singaringan. In contrast, in $M$. wolffi, $\mathrm{d}(\mathrm{GC})_{15}$ repeats are dispersed throughout all chromosomes, while $\mathrm{d}(\mathrm{CAA})_{10}$ repeats are accumulated at telomeric positions of some chromosome pairs with more density in only one pair. The $\mathrm{d}(\mathrm{CAT})_{10}$ repeats in $M$. atrifasciatus and $M$. mysticetus display high accumulations at the telomeric regions of almost all chromosomes and interstitial sites in some pairs whereas they have high accumulations at only the telomeric regions of almost all chromosomes in M. singaringan, and highly distributed in some chromosome pairs in M. wolffii. The $\mathrm{d}(\mathrm{GAA})_{10}$ repeats are abundantly distributed at interstitial and telomeric regions of several chromosome pairs in $M$. mysticetus, $M$. singaringan and $M$. wolffi, while they are highly accumulated in some chromosome pairs of $M$. atrifasciatus (Fig. 3; Table 2).

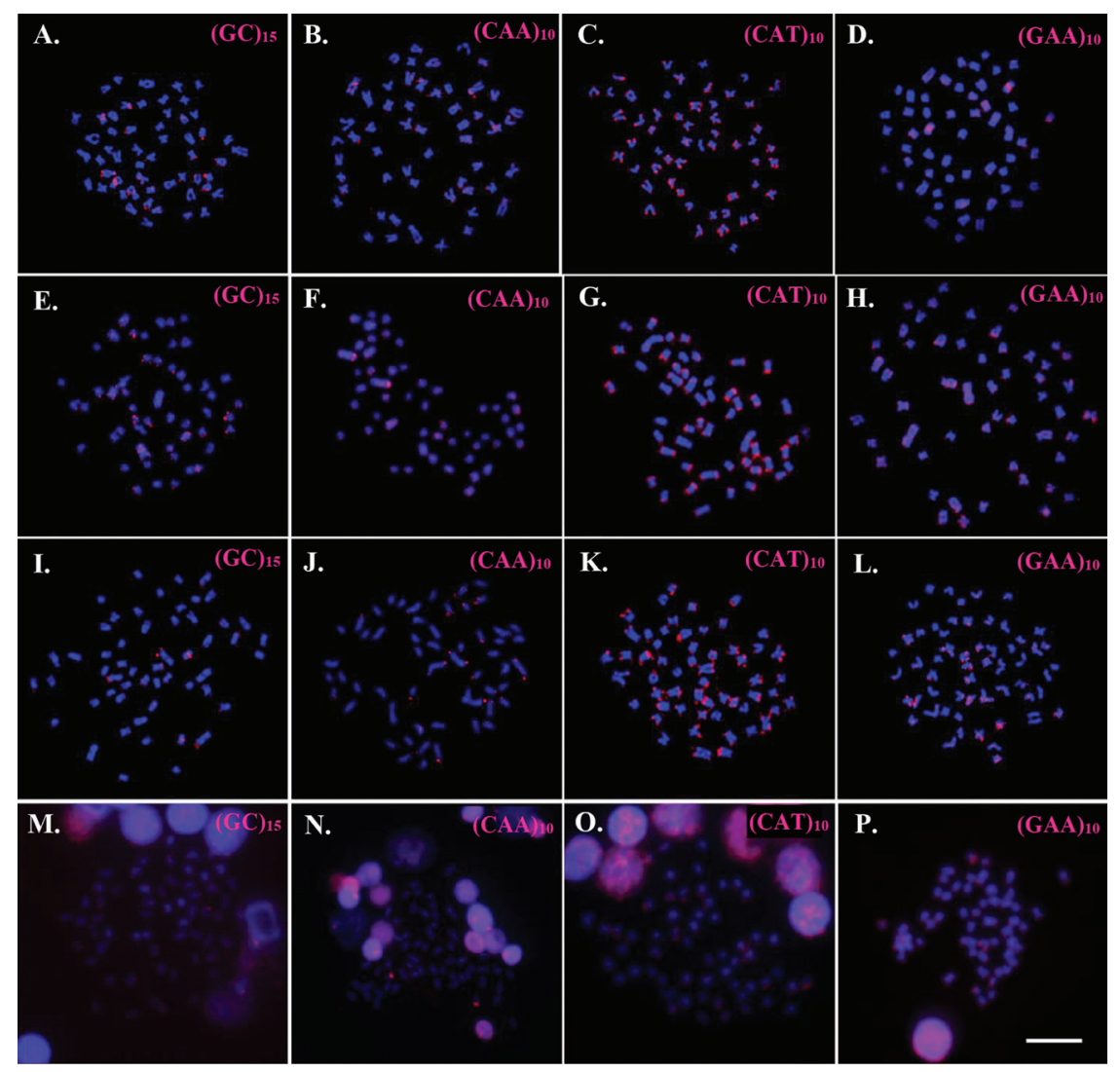

Figure 3. Metaphase chromosome plates showing $\mathrm{d}(\mathrm{GC})_{15}, \mathrm{~d}(\mathrm{CAA})_{10}, \mathrm{~d}(\mathrm{CAT})_{10}$ and $\mathrm{d}(\mathrm{GAA})_{10}$ microsatellites mapping on chromosomes of Mystus atrifasciatus $(\mathbf{A}, \mathbf{E}, \mathbf{I}, \mathbf{M})$, M. mysticetus $(\mathbf{B}, \mathbf{F}, \mathbf{J}, \mathbf{N}), M$. singaringan $(\mathbf{C}, \mathbf{G}, \mathbf{K}, \mathbf{O})$ and $M$. wolffi $(\mathbf{D}, \mathbf{H}, \mathbf{L}, \mathbf{P})$. Scale bars: $5 \mu \mathrm{m}$. 


\section{Discussion}

\section{Diploid chromosome numbers, fundamental numbers and karyotypes of M. atrifasciatus, M. mysticetus, M. singaringan and M. wolffii}

The diploid chromosome numbers $(2 \mathrm{n})$ in all analyzed species confirmed previous cytogenetic studies (Donsakul 2000, 2001; Magtoon and Donsakul 2009; Supiwong et al. 2014a, b), except for $M$. mysticetus with $2 \mathrm{n}=50$ reported in a previous study (Donsakul 2002) and 52 in the present one. In agreement with the literature, $2 \mathrm{n}$ in the genus Mystus ranges between 50 and 58 chromosomes (Arai 2011; Table 1). The possible mechanisms that promoted intra- and interspecific karyotype diversification are biogeographic barriers, small population, limited gene flow (Galetti Jr et al. 2000). Although all studied species except $M$. mysticetus, had the same $2 \mathrm{n}$ as previous studies, the karyotypes were different, probably because of different sampling sites should be considered (Fig. 4). The predominant $2 \mathrm{n}$ in this genus is 56 chromosomes (five from 13 species) and may represent an ancestral character in this family (Sharma and Tripathi 1986). This is consistent with the hypothesis of Oliveira and Gosztonyi (2000) that $2 \mathrm{n}=56$ could be a plesiomorphic character in the order Siluriformes. However, NF and karyotypes found in the present study differ from all previous reports (Donsakul 2000, 2001, 2002; Magtoon and Donsakul 2009; Supiwong et al. 2014a, b). These differences may be species-specific variations within populations, and/or misidentification of species, or different species in presumed species complexes. NF in Mystus vary from 64 to 110 . Ghigliotti et al. (2007) suggested that species with a higher NF value are more advanced in evolutionary terms than such with lower one. That hypothesis can be described that primitive karyotype of fish possesses many acrocentric chromosomes (mono-arm chromosomes). During evolution, the mono-arm chromosomes changed to bi-arm chromosomes. The NF would be unaltered, but the $2 \mathrm{n}$ would decrease. Changes in NF appear to be related to the occurrence of pericentric inversions, which play a major role for karyotypic rearrangement in fishes and other vertebrates (King 1993; Galetti Jr et al. 2000; Wang et al. 2010). Accordingly, from comparative analysis among the here studied four Mystus species, NF data and analyses of karyotypic complements indicate for that $M$. singaringan has the most primitive karyotype while M. wolffi has the most derivative karyotype. As often seen in fishes of this family, no heteromorphic sex chromosomes for males and females could be identified. Nonetheless it must be mentioned, that there are two species, M. gulio (Hamilton, 1822) and M. tengara (Hamilton, 1822), which have differentiated sex chromosome systems as $\mathrm{XX} / \mathrm{XY}$ and ZZ/ZW, respectively (Arai 2011). Accordingly, differentiated sex chromosome system in this fish group seems to be a quite rare phenomenon.

Karyotypes of the genus Mystus in Thailand showed high diversification (Table 1). Seven species have been cytogenetically studied. The $2 \mathrm{n}$ ranged between 50 chromosomes in M. mysticetus (Donsakul 2002) and 58 chromosomes in M. wolffi (Donsakul 2000; present study). The predominant 2n is 56 chromosomes found in $M$. albolineatus $(\mathrm{NF}=108,28 \mathrm{~m}+6 \mathrm{sm}+12 \mathrm{st}+10 \mathrm{a}$ ) (Donsakul 2000), M. bocourti 


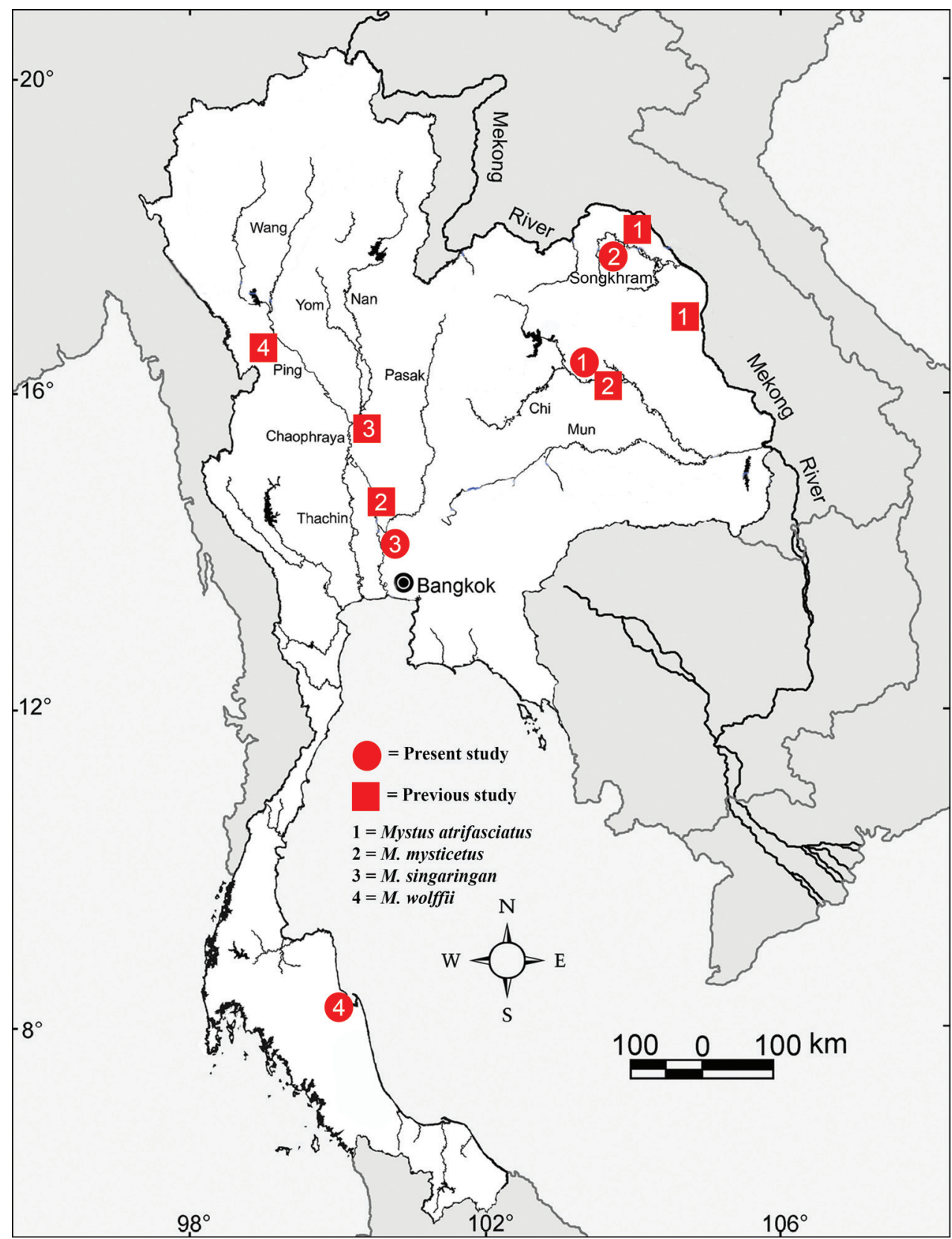

Figure 4. Map showing the comparison of sampling sites among present and previous studies.

$(\mathrm{NF}=100,22 \mathrm{~m}+22 \mathrm{sm}+12 \mathrm{st} / \mathrm{a} ; \mathrm{NF}=104,24 \mathrm{~m}+18 \mathrm{sm}+6 \mathrm{st}+8 \mathrm{a})($ Donsakul 2000; Supiwong et al. 2013a, 2014a, b) and $M$. singaringan $(\mathrm{NF}=94,24 \mathrm{~m}+14 \mathrm{sm}+10 \mathrm{st}+8 \mathrm{a}$; $\mathrm{NF}=98,24 \mathrm{~m}+18 \mathrm{sm}+14 \mathrm{a}$ ) (Donsakul 2001; present study). Our results showed differences among NFs and karyotypes in the studied species. Interestingly, M. mysticetus 
had two variants, $2 \mathrm{n}=50$ chromosomes $(\mathrm{NF}=92,28 \mathrm{~m}+14 \mathrm{sm}+8 \mathrm{a})$, found in Ayutthaya Province, Central Thailand (Donsakul 2002), and 52 chromosomes $(\mathrm{NF}=100$, $26 m+22 s m+4 s t / a ; N F=102,26 m+24 s m+2 a)$ found in Maha Sarakham and Bueng Kan Provinces, Northeast of Thailand (Supiwong et al. 2014a, b; present study) (Fig. 4). This variation may be caused by a rearrangement of chromosomes by centric fusion and pericentric inversion during chromosomal evolution in groups of populations separated by a geographic barrier.

\section{Chromosome markers for M. atrifasciatus, M. mysticetus, M. singaringan and M. wolffii}

\section{Nucleolus organizer regions (NORs)}

The localization of nucleolus organizer regions (NORs) is a simple method to determine chromosomal marker. NORs are specific positions on the chromosome that consist of tandemly repeated sequences of ribosomal genes (rRNA). In eukaryotes, each unit is composed of three genes coding for 18S, 5.8S and 28S ribosomal RNA (Sharma et al. 2002). Generally, most fishes have one pair of small NORs (single NOR) on chromosomes. However, some species of fishes have more than two NORs which may be caused by the translocation between some part of the chromosome with NORs and another chromosome (Sharma et al. 2002). Interspecific and intraspecific NOR polymorphism in the number of NORs per genome, in the chromosomal location of NOR sites, in the relative sizes of individual NORs, and in the number of active NOR sites per cell are commonly observed in fish, where the rDNA loci have been shown to be highly dynamic (Milhomem et al. 2013). Changes in chromosome number and structure can alter the number and structure of NOR as well. The pattern of NORs may be specific to populations, species and subspecies. Robertsonian translocations may cause losses of NOR. Species, which have limited gene exchange due to geographical isolation, have elevated karyotype numbers and NOR variation. (Yüksel and Gaffaroğlu 2008). The NOR is frequently used to compare variations as well as to identify and explain specifications. Therefore, it can be used as taxonomic and systematic characters in order to infer phylogenetic hypotheses of species relationships (Gold 1984; Amemiya and Gold 1990).

If these loci are active during the interphase before mitosis, they can be detected by silver nitrate staining (Howell and Black 1980). The single NOR-bearing chromosome pairs in the present study is consistent in M. cavasius (Hamilton, 1822) (Sharma and Tripathi 1986; Rishi et al. 1994), M. gulio (Das and Khuda-Bukhsh 2007b), and M. vittatus (Khuda-Bukhsh and Barat 1987; John et al. 1992). This character is a common characteristic found in many species in this family such as Bagrichthys majusculus $\mathrm{Ng}, 2002$ (Supiwong et al. 2018), He. menoda (Hamilton, 1822) (Barat and KhudaBukhsh 1986), He. wyckii (Bleeker, 1858) (Supiwong et al. 2017c), Horabagrus brachysoma (Günther, 1864) (Nagpure et al. 2003), Ho. nigricollaris Pethiyagoda et Kottelat, 1994 (Nagpure et al. 2004), Pelteobagrus ussuriensis (Dybowski, 1872) (Kim et al. 
1982), Pseudobagus vachelii (Ueno 1985), Pseudomystus siamensis (Regan, 1913) (Supiwong et al. 2013b), Rita rita (Hamilton, 1822) (Khuda-Bukhsh and Barat 1987) and Sperata seenghala (Sykes, 1839) (Sharma and Tripathi 1986; Das and Khuda-Bukhsh 2007a). However, only a single species, Tachysurus fulvidraco (Richardson, 1846), has two NOR carrying chromosome pairs (Zhang et al. 1992). In fishes, a single NOR carrying chromosome pair is considered as a primitive state (Milhomem et al. 2013). Many families such as Chaetodontidae (Supiwong et al. 2017a), Lutjanidae (Phimphan et al. 2017), Notopteridae (Maneechot et al. 2015), Scaridae (Kaewsri et al. 2014), Serranidae (Pinthong et al. 2013), share this character. Also, for fishes the location of NORs in a terminal position, as seen in the studied species, is also considered as a primitive characteristic (Vitturi et al. 1995).

\section{Patterns of microsatellite repeats on the genomes of Mystus atrifasciatus, M. mysticetus, M. singaringan and M. wolffii}

Repetitive DNAs like microsatellites can be used to spot genomic evolution as previously been reported for different fish groups (Cioffi et al. 2010; Cioffi and Bertollo 2012; Terencio et al. 2013; Yano et al. 2014; Cioffi et al. 2015; Moraes et al. 2017, 2019; Sassi et al. 2019). It is known from fossil records that there is a major evolutionary diversification in Siluriformes fishes; this has in parts already also been verified at chromosomal level.

Here, four bi- and tri-nucleotide microsatellite sequences were mapped on chromosomes of four Mystus species. The patterns of microsatellites d(GC) ${ }_{15}$ and d(CAA) ${ }_{10}$ repeats in three species in the present study (M. atrifasciatus, M. mysticetus, M. singaringan) are similar to those found in Channa micropeltes (Cuvier, 1831) (Cioffi et al. 2015). On the other hand, they are differences known for C. gachua (Hamilton, 1822), C. lucius (Cuvier, 1831), C. striata (Bloch, 1793) (Cioffi et al. 2015), Toxotes chatareus (Hamilton, 1822) (Supiwong et al. 2017b) and Asian swamp eel, Monopterus albus (Zuiew, 1793) (Supiwong et al. 2019). The pattern of microsatellite d(GC) repeats in $M$. wolffi is similar to that of $C$. lucius (Cioffi et al. 2015) and T. chatareus (Supiwong et al. 2017a). Interestingly, the patterns of microsatellite d(CAT) ${ }_{10}$ repeats in $M$. atrifasciatus, $M$. mysticetus and $M$. singaringan are similar to the patterns of the (CA) ${ }_{15}$ repeats on chromosomes of other species in the family Bagridae (Supiwong et al. 2013a, 2014b). Comparative study on four species showed that not only there are differences of 2n, NF and karyotype, but the patterns of microsatellite repeat on chromosomes also have difference among them. Thus, the cytogenetic data may be a tool for classification of fish species that there is similar morphology as the stripe Mystus (M. atrifasciatus and M. mysticetus).

From previous reports, it may be carefully deduced that most heterochromatin in fish genomes consist of microsatellites (Cioffi and Bertollo 2012). However, microsatellites have also been found in non-centromeric regions, many of them were located either near or within genes (Rao et al. 2010; Getlekha et al. 2016). Indeed, GC rich motifs are common in exons of all vertebrates (Chistiakov et al. 2006). Since higher re- 
combination rates can be found near the telomeric region (Jensen-Seaman et al. 2004), it is possible that the physical proximity of microsatellite and rDNA repeats could favor the evolutionary spreading of both sequences together, despite the possibility of spreading some errors, too. Repetitive DNA sequences could act as primary driving forces in speciation (Biémont and Vieira 2006). These sequences are closely associated with heterochromatic regions, thus contributing to gene activation and structural maintenance of chromosomes (Dernburg et al. 1996). Therefore, great variations in the amount and position of these sequences could create fertility barriers by fostering the occurrence of chromosomal rearrangements (Cioffi and Bertollo 2012).

Indeed, the distribution of microsatellite motifs in fish genomes could be biased to some specific noncoding regions, as found in the Asian swamp eel, M. albus ( $\mathrm{Li}$ et al. 2017). Finally, closely related fish species involved in recent speciation events could present a differential pattern in the distribution and quantity of microsatellite sequences on chromosomes, as demonstrated for naked catfishes (Supiwong et al. 2014b), channid fishes (Cioffi et al. 2015) and four Mystus in the present study.

\section{Conclusions}

The present research is the first report on NOR and microsatellites $\mathrm{d}(\mathrm{GC})_{15}, \mathrm{~d}(\mathrm{CAA})_{10}$, $\mathrm{d}(\mathrm{CAT})_{10}$ and $\mathrm{d}(\mathrm{GAA})_{10}$ mapping in M. atrifasciatus, $M$. mysticetus, $M$. singaringan and M. wolffii. There are differences in the diploid chromosome number, the fundamental numbers, karyotypes, pairs having NORs, and patterns of microsatellite distributions on chromosomes. These results indicated that (molecular) cytogenetic data can be used for classification in related fish species and to explain karyotype diversification.

\section{Acknowledgments}

This work was financially supported by the Research Fund for DPST Graduate with First Placement Year 2015, Development Promotion of Science and Technology Talents project (DPST), the Post-Doctoral Training Program from Research Affairs and Graduate School (Grant no 59255), Khon Kaen University, and Unit of Excellence 2020 on Biodiversity and Natural Resources Management, University of Phayao (UoE63005), Thailand.

\section{References}

Amemiya CT, Gold JR (1990) Cytogenetic studies in North American minnows (Cyprinidae): XVII. Chromosomal NOR phenotypes of 12 species, with comments on cytosystematic relationships among 50 species. Hereditas 112(3): 231-247. https://doi. org/10.1111/j.1601-5223.1990.tb00062.x 
Arai R (2011) Fish Karyotypes: A Check List. Springer Japan, Tokyo. https://doi. org/10.1007/978-4-431-53877-6

Barat A, Khuda-Bukhsh AR (1986) Karyomorphometrical studies in two species of fishes, Lepidocephalichthys guntea (fam.: Cobitidae) and Mystus corsula (fam.: Bagridae). Perspectives in Cytology and Genetics 5: 115-118.

Biémont C, Vieira C (2006) Junk DNA as an evolutionary force. Nature 443(7111): e521. https://doi.org/10.1038/443521a

Chanda TA (1989) Study of chromosome in some hill stream fishes of Assam India. Ph.D. Thesis. Kalyani University, West Bengal.

Chistiakov DA, Hellemans B, Volckaert FA (2006) Microsatellites and their genomic distribution, evolution, function and applications: a review with special reference to fish genetics. Aquaculture 255(1-4): 1-29. https://doi.org/10.1016/j.aquaculture.2005.11.031

Choudhury RC, Prasad R, Das CC (1993) Chromosomes of four Indian marine catfishes (Bagridae, Ariidae: Siluriformes) with a heteromorphic pair in male Mystus gulio. Caryologia 46: 233-243. https://doi.org/10.1080/00087114.1993.10797264

Cioffi MB, Bertollo LAC (2012) Distribution and evolution of repetitive DNAs in fish. In: Garrido-Ramos MA (Ed.) Repetitive DNA. Karger, Genome Dynamics (Vol. 7). Basel, 197-221. https://doi.org/10.1159/000337952

Cioffi MB, Bertollo LAC, Villa MA, Oliveira EA, Tanomtong A, Yano CF, Supiwong W, Chaveerach A (2015) Genomic organization of repetitive DNA elements and its implications for the chromosomal evolution of channid fishes (Actinopterygii, Perciformes). PLoS ONE 12: 1-13. https://doi.org/10.1371/journal.pone.0130199

Cioffi MB, Martins C, Bertollo LAC (2010) Chromosome spreading of associated transposable elements and ribosomal DNA in the fish Erythrinus erythrinus. Implications for genome change and karyoevolution in fish. BMC Evolutionary Biology 10(1): 271-279. https:// doi.org/10.1186/1471-2148-10-271

Das JK, Khuda-Bukhsh AR (2007a) GC-rich heterochromatin in silver stained nucleolar organizer regions (NORs) fluoresces with chromomycin $\mathrm{A}_{3}\left(\mathrm{CMA}_{3}\right)$ staining in three species of teleostean fishes (Pisces). Indian Journal of Experimental Biology 45: 413-418.

Das JK, Khuda-Bukhsh AR (2007b) Preponderance of GC-rich sites in silver stained nucleolus organizing regions of Rita rita (Hamilton) and Mystus gulio (Hamilton) (Bagridae, Pisces), as revealed by chromomycin A3-staining technique and scanning electron microscopic studies. Genetics and Molecular Research 6: 284-291.

Das RK, Kar RN (1977) Somatic chromosome analysis of a siluroid fish, Rita chrysea Day. Caryologia 30: 247-253. https://doi.org/10.1080/00087114.1977.10796698

Das B, Srivastava MDL (1973) The meiotic chromosomes of certain Indian teleosts. Proceedings of National Academy of Science, India 43: 29-40.

Dernburg AF, Sedat JW, Hawley RS (1996) Direct evidence of a role for heterochromatin in meiotic chromosome segregation. Cell 86: 135-146. https://doi.org/10.1016/S00928674(00)80084-7

Donsakul T (2000) Chromosome study on three species of bagrid catfishes, Mystus albolineatus, $M$. wolffi and Heterobagrus bocourti, from Thailand. Proceedings of the $38^{\text {th }}$ Kasetsart University Annual Conference: Fisheries and Science. Kasetsart University, Bangkok, 217-226. [In Thai] 
Donsakul T (2001) Chromosome study on four species of bagrid catfishes, Mystus nemurus, $M$. wyckii, M. wyckioides and M. singaringan, from Thailand. Proceedings of the $39^{\text {th }}$ Kasetsart University Annual Conference: Fisheries and Science. Kasetsart University, Bangkok, 209-219. [In Thai]

Donsakul T (2002) Chromosome study on four species of bagrid catfishes, Mystus mysticetus, Leiocassis siamensis, Bagrichthys macropterus and B. macracanthus, from Thailand. Proceedings of the $40^{\text {th }}$ Kasetsart University Annual Conference: Animal, Fisheries and Science. Kasetsart University, Bangkok, 681-691. [In Thai]

Ferdous S (2013) Geometric Morphometrics and Phylogeny of the Catfish genus Mystus Scopoli (Siluriformes:Bagridae) and North American Cyprinids (Cypriniformes). Doctor of Philosophy Dissertation. Auburn University, Auburn.

Galetti Jr PM, Aguilar CT, Molina WF (2000) An overview of marine fish cytogenetics. Hydrobiologia 420: 55-62. https://doi.org/10.1023/A:1003977418900

Getlekha N, Molina WF, Cioffi MB, Yano CF, Maneechot N, Bertollo LAC, Supiwong W, Tanomtong A (2016) Repetitive DNAs highlight the role of chromosomal fusions in the karyotype evolution of Dascyllus species (Pomacentridae, Perciformes). Genetica 144: 203211. https://doi.org/10.1007/s10709-016-9890-5

Ghigliotti L, Mazzei F, Ozouf-Costaz C, Bonillo C, Williams R, Cheng CHC, Pisano E (2007) The two giant sister species of the Southern Ocean, Dissostichus eleginoides and Dissostichus mawsoni, differ in karyotype and chromosomal pattern of ribosomal RNA genes. Polar Biology 30: 625-634. https://doi.org/10.1007/s00300-006-0222-6

Gold JR (1984) Silver-staining and heteromorphism of chromosomal nucleolus organizer regions in North American cyprinid fishes. Copeia 23: 133-139. https://doi. org/10.2307/1445043

Howell WM, Black DA (1980) Controlled silver-staining of nucleolus organizer regions with a protective colloidal developer: a 1-step method. Experientia 36: 1014-1015. https://doi. org/10.1007/BF01953855

Jensen-Seaman MI, Furey TS, Payseur BA, Lu Y, Roskin KM, Chen CF, Thomas MA, Haussler D, Jacob HJ (2004) Comparative recombination rates in the rat, mouse, and human genomes. Genome Research 14(4): 528-538. https://doi.org/10.1101/gr.1970304

John G, Barat A, Lakra WS (1992) Localization of nucleolar organizer regions in fish species, Catla catla and Mystus vittatus. Nucleus 35: 179-181.

Kaewsri S, Tanomtong A, Getlekha N, Saenjundaeng P, Suksuwan R, Supiwong W (2014) Standardized karyotype and idiogram of Quoy's parrotfish, Scarus quoyi (Perciformes: Scaridae) by conventional staining and Ag-NOR banding techniques. Cytologia 79(4): 429-435. https://doi.org/10.1508/cytologia.79.429

Khuda-Bukhsh AR, Barat A (1987) Chromosomes in fifteen species of Indian teleosts (Pisces). Caryologia 40: 131-144. https://doi.org/10.1080/00087114.1987.10797817

Khuda-Bukhsh AR, Das JK (2007) Cytogenetic analyses in eight species of teleostean fishes (Pisces): karyotypes, multiple Ag-NORs, sex chromosomes. Research and Reviews in BioSciences (India) 1: 47-52.

Khuda-Bukhsh AR, Gupta SK, Goswami S (1980) Karyotypic studies in Garra lamta and Mystus cavassius (Pisces). Proceedings of the National Academy of Sciences, India Section B: Biological Sciences 89: 557-562. https://doi.org/10.1007/BF03179055 
King M (1993) Species Evolution: The Role of Chromosomes Change. Cambridge University Press, Cambridge, 336 pp.

Kim DS, Park EH, Kim JS (1982) Karyotypes of nine species of the Korean catfishes (Teleostomi: Siluriformes). Korean Journal of Genetics 4: 57-68.

Kubat Z, Hobza R, Vyskot B, Kejnovsky E (2008) Microsatellite accumulation in the Y chromosome of Silene latifolia. Genome 51: 350-356. https://doi.org/10.1139/G08-024

Levan A, Fredga K, Sandberg AA (1964) Nomenclature for centromeric position on chromosomes. Hereditas 52: 201-220. https://doi.org/10.1111/j.1601-5223.1964.tb01953.x

Li Z, Chen F, Huang C, Zheng W, Yu C, Cheng H, Zhou R (2017) Genome-wide mapping and characterization of microsatellites in the swamp eel genome. Scientific Reports 7: e3157. https://doi.org/10.1038/s41598-017-03330-7

Magtoon W, Donsakul T (2009) Karyotypes of five bagrid catfishes (family Bagridae): Mystus multiradiatus, M. castaneus, M. atrifasciatus, Batasio havmolleri and Sperata acicularis from Thailand. In: Proceedings of the $47^{\text {th }}$ Kasetsart University Annual Conference, Kasetsart, Fisheries. Kasetsart University, Bangkok, 328-336.

Manna GK, Prasad R (1974) Cytological evidence for two forms of Mystus vittatus (Bloch) as two species. Nucleus 17: 4-8.

Maneechot N, Supiwong W, Jumrusthanasan S, Siripiyasing P, Suvarnaraksha A, Tanomtong A (2015) Chromosomal characteristics of the royal knifefish, Chitala blanci (Osteoglossiformes, Notopteridae) by conventional and Ag-NOR staining techniques. Cytologia 80(2): 159-166. https://doi.org/10.1508/cytologia.80.159

Mengampan K, Manosoy J, Meevetee A, Manosoy A (2004) Chromosomal Karyotyping from Peripheral Blood Lymphocytes of the Mekong Giant Catfish (Pangasianodon gigas, Chevey). Thai Fisheries Gazette 57(4): 349-351. [In Thai]

Milhomem SSR, Scacchetti PC, Pieczarka JC, Ferguson-Smith MA, Pansonato-Alves JC, O'Brien PCM, Foresti F, Nagamachi CY (2013) Are NORs always located on homeologous chromosomes? a FISH investigation with rDNA and Whole Chromosome Probes in Gymnotus fishes (Gymnotiformes). PLoS ONE 8(2): e55608. https://doi.org/10.1371/ journal.pone.0055608

Moraes RLR, Bertollo LAC, Marinho MMF, Yano CF, Hatanaka T, Barby FF, Troy WP, Cioff MB (2017) Evolutionary relationships and cytotaxonomy considerations in the genus Pyrrhulina (Characiformes, Lebiasinidae). Zebrafish 14(6): 536-546. https://doi. org/10.1089/zeb.2017.1465

Moraes RLR, Sember A, Bertollo LAC, de Oliveira EA, Ráb P, Hatanaka T, Marinho MMF, Liehr T, Al-Rikabi ABH, Feldberg E, Viana PF, Cioffi MB (2019) Comparative cytogenetics and neo-Y formation in small-sized fish species of the genus Pyrrhulina (Characiformes, Lebiasinidae). Frontiers in Genetics 10: e678. https://doi.org/10.3389/ fgene.2019.00678

Nagpure NS, Kumar R, Srivastava SK, Gopalakrishnan A, Verma MS, Baseer VS (2004) Cytogenetic studies of fish species Horabagrus nigricollaris, Puntius denisonii and Puntius sarana subnasutus endemic to the Western Ghats. Nucleus 47: 143-148.

Nagpure NS, Kushwaha B, Srivastava SK, Kumar R, Gopalakrishnan A, Baseer VS, Verma MS (2003) Characterization of three endemic fish species from Western Ghats using cytogenetic markers. The Nucleus 46: 110-114. 
Na-Nakorn U, Tarnchalanukit W, Taptippawan P (1980) Induction of triploidy in Clarias batrachus by cold shock. Kasetsart Journal 22: 116-121. [In Thai]

Nayyar RP (1966) Karyotypic studies in thirteen species of fishes. Genetica 37: 78-92. https:// doi.org/10.1007/BF01547121

Ng HH (2003) Phylogeny and Systematics of Bagridae. In: Arratia G, Kapoor BG, Chardon M, Diogo R (Eds) Catfishes. Science Publishers Inc., Enfield, 439-463.

Oliveira C, Gosztonyi AE (2000) A cytogenetic study of Diplomystes mesembrinus (Teleostei, Siluriformes, Diplomystidae) with a discussion of chromosome evolution in Siluriforms. Caryologia 53(1): 31-37. https://doi.org/10.1080/00087114.2000.10589178

Phimphan S, Supiwong W, Tanomtong A, Pinthong K, Sangpakdee W, Kaewsri S (2017) Karyotypic study of five Lutjanid species using conventional and Ag-NORs banding techniques. Cytology and Genetics 51(4): 315-324. https://doi.org/10.3103/S0095452717040077

Pinkel D, Straume T, Gray J (1986) Cytogenetic analysis using quantitative, high sensitivity, fluorescence hybridization. Proceedings of the National Academy of Sciences of the United States of America 83: 2934-2938. https://doi.org/10.1073/pnas.83.9.2934

Pinthong K, Gomontean B, Kongim B, Khakhong S, Sriveerachai T, Supiwong W (2013) Cytogenetic comparisons of four genera in Grouper species (Pisces, Epinephelinae), and chromosome localization of the nucleolar organizer region from Thailand. Cytologia 78(3): 223-234. https://doi.org/10.1508/cytologia.78.223

Ramasamy K, Bela Z, Kamatchi B (2010) Karyotype of a bagid catfish, Mystus vittatus, from the freshwater system of Chidambaram, Tamilnadu, India. Science Asia 36: 157-160. https://doi.org/10.2306/scienceasia1513-1874.2010.36.157

Rao SR, Trivedi S, Emmanue D, Merita K, Hynniewta M (2010) DNA repetitive sequencestypes, distribution and function: A review. Journal of Cell and Molecular Biology 7: 1-11.

Rishi KK (1973) Somatic karyotypes of three teleosts. Genen Phaenen 16(3): 101-107.

Rishi KK (1981) Chromosomal studies on four cyprinid fishes. International Journal of Academy of Ichthyology 2: 1-4.

Rishi KK, Rishi S (1981) Giemsa banding in fish chromosomes. Perspectives in cytology and genetics 3: 103-106.

Rishi S, Rishi KK, Thind ADK (1994) NOR Studies in six species of the genus Mystus (Bagridae, Osteichthyes). Proceedings of the VIII European Congress of Ichthyology, Oviedo, 59 pp.

Sassi FMC, Oliveira EAD, Bertollo LAC, Nirchio M, Hatanaka T, Marinho MMF, Moreira-Filho O, Aroutiounian R, Liehr T, Al-Rikabi ABH, Cioffi MB (2019) Chromosomal evolution and evolutionary relationships of Lebiasina species (Characiformes, Lebiasinidae). International Journal of Molecular Sciences 20(12): e2944. https://doi.org/10.3390/ ijms20122944

Sharma OP, Tripathi NK (1986) Karyotypic diversity in genus Mystus (Bagridae: Pisces). Cytologia 51: 1-9. https://doi.org/10.1508/cytologia.51.1

Sharma OP, Tripathi NK, Sharma KK (2002) A review of chromosome banding in fishes. In: Sobti RC (Ed.) Some Aspects of Chromosome Structure and Functions. New Narosa Publishing House, Delhi, 109-122. https://doi.org/10.1007/978-94-010-0334-6_11

Sing SS, Sing CB, Waikhom G (2013) Karyotype analysis of the new catfish Mystus ngasep (Siluriformes: Bagridae) from Manipur, India. Turkish Journal of Fisheries and Aquatic Sciences 13: 179-185. 
Sofy HI, Layla AM, Iman MKA (2008) Karyotypic diversity of some tilapia species. Nature and Science 6(1): 19-27.

Supiwong W, Boonsuk J, Tanomtong A, Suvarnaraksha A, Kaewsri S (2017a) The first chromosomal characteristics of nucleolar organizer regions and karyological analysis of two Chaetodontid fishes (Perciformes, Chaetodontidae). Cytologia 82(1): 33-39. https://doi. org/10.1508/cytologia.82.33

Supiwong W, Getlakha N, Chaiphech S, Pinthong K, Phimphan S, Tanomtong A (2018) Nucleolar organizer regions polymorphism and karyological analysis of black Lancer, Bagrichthys majusculus (Siluriformes, Bagridae) in Thailand. Cytologia 83(2): 193-199. https:// doi.org/10.1508/cytologia.83.193

Supiwong W, Jiwyam W, Sreeputhorn K, Maneechot N, Bertollo LAC, Cioffi MB, Getlekha N, Tanomtong A (2017b) First report on classical and molecular cytogenetics of archerfish, Toxotes chatareus (Perciformes: Toxotidae). Nucleus 60: 349-359. https://doi.org/10.1007/ s13237-017-0216-5

Supiwong W, Liehr T, Cioffi MB, Chaveerach A, Kosyakova N, Pinthong K, Tanee T, Tanomtong A (2013a) Karyotype and cytogenetic mapping of 9 classes of repetitive DNAs in the genome of the naked catfish Mystus bocourti (Siluriformes, Bagridae). Molecular Cytogenetics 6(1): e51. https://doi.org/10.1186/1755-8166-6-51

Supiwong W, Liehr T, Cioffi MB, Chaveerach A, Kosyakova N, Fan X, Tanee T, Tanomtong A (2014a) Comparative cytogenetic mapping of rRNA genes among naked catfishes: implications for genomic evolution in the Bagridae family. Genetics and Molecular Research 13 (4): 9533-9542. https://doi.org/10.4238/2014.November.12.2

Supiwong W, Liehr T, Cioffi MB, Chaveerach A, Kosyakova N, Pinthong K, Tanee T, Tanomtong A (2014b) Chromosomal evolution in naked catfishes (Bagridae, Siluriformes): A comparative chromosome mapping study. Zoologischer Anzeiger-A Journal of Comparative Zoology 253(4): 316-320. https://doi.org/10.1016/j.jcz.2014.02.004

Supiwong W, Pinthong K, Seetapan K, Saenjundaeng P, Bertollo LAC, de Oliveira EA, Yano CF, Liehr T, Phimphan S, Tanomtong A, Cioffi M B (2019) Karyotype diversity and evolutionary trends in the Asian swamp eel Monopterus albus (Synbranchiformes, Synbranchidae): a case of chromosomal speciation? BMC Evolutionary Biology 19: e73. https://doi. org/10.1186/s12862-019-1393-4

Supiwong W, Saenjundaeng P, Maneechot N, Chooseangjaew S, Pinthong K, Tanomtong A (2017c) A discovery of nucleolar organizer regions (NORs) polymorphism and karyological analysis of Crystal eye catfish, Hemibagrus wyckii (Siluriformes, Bagridae) in Thailand. Cytologia 82(4): 403-411. https://doi.org/10.1508/cytologia.82.403

Supiwong W, Tanomtong A, Jumrusthanasan S, Khakhong S, Leelarasamee K, Sanoamuang L (2012) A first karyotype analysis and chromosomal characteristic of nucleolar organizer regions (NORs) of common sheathfish, Micronema apogon (Siluriformes, Siluridae) in Thailand. Cytologia 77(1): 53-58. https://doi.org/10.1508/cytologia.77.53

Supiwong W, Tanomtong A, Chaveerach A, Tanee T, Khakhong S, Sanoamuang L (2013b) Interpopulational variation of NOR positions and karyotypic analysis of Siamese catfish (Pseudomystus siamensis) in Thailand. Cytologia 78: 25-34. https://doi.org/10.1508/cytologia.78.25

Tanomtong A (2011) Cytogenetics. Khon Kaen University press, Khon Kaen. [in Thai] 
Terencio ML, Schneider CH, Gross MC, Vicari MR, Farias IP, Passos KB, Feldberg E (2013) Evolutionary dynamics of repetitive DNA in Semaprochilodus (Characiformes, Prochilodontidae): a fish model for sex chromosome differentiation. Sexual Development 7(6): 325-333. https://doi.org/10.1159/000356691

Tripathi NK, Das CC (1980) Chromosomes in three species of Asian catfish. Copeia 1980: 916-918. https://doi.org/10.2307/1444487

Ueno K (1985) Karyotypes of bagrid catfishes in Japan and Korea. Marine Sciences Monthly 17(2): 102-108.

Vidthayanon C (2005) Handbook of Freshwater Fish (2 $2^{\text {nd }}$ ed.). Sarakadee Press, Bangkok. [In Thai]

Vitturi R, Catalano E, Colomba MS, Montagnino L, Pellerito L (1995) Karyotype analysis of Aphanius fasciatus (Pisces, Cyprinodontiformes): Ag-NORs and C-band polymorphism in four populations from Sicily. Biologisches Zentralbatt 114: 392-402.

Yano CF, Bertollo LAC, Cioffi MB (2017) Fish-FISH: Molecular cytogenetics in fish species. In: Liehr T (Ed.) Fluorescence in situ Hybridization (FISH)-Application Guide. Springer, Berlin, 427-444. https://doi.org/10.1007/978-3-662-52959-1_44

Yano CF, Poltronieri J, Bertollo LAC, Artoni RF, Liehr T, Cioffi MB (2014) Chromosomal mapping of repetitive DNAs in Triportheus trifurcatus (Characidae, Characiformes): insights into the differentiation of the Z and W chromosomes. PLoS ONE 9(3): e90946. https://doi.org/10.1371/journal.pone.0090946

Yüksel E, Gaffaroğlu M (2008) NOR phenotype of Cyprinion macrostomus (Osteichthyes, Cyprinidae). Journal of Fisheries Sciences 2: 114-117. https://doi.org/10.3153/jfscom.2008012

Zhang SM, Zheng Y, Yao H, Zhang XZ (1992) Nucleolar organizer regions in four species of fishes. Chromosome Information Service 53: 6-8. 